\title{
領域積分方程式を用いた弾性波動場の散乱 および逆散乱解析手法の展開
}

Forward and inverse scattering analysis of elastic wave field by means of the volume integral equation method.

\author{
東平光生*・岩崎健太郎** - 小林遼 ${ }^{* *}$ ・ 木内拓 ${ }^{* *}$ \\ Terumi TOUHEI, Kentaro IWASAKI, Ryo KOBAYASHI, Taku KIUCHI \\ *正会員 工博 東京理科大学教授 理工学部 土木工学科（广 278-8510 千葉県野田市山猗 2641） \\ **学生会員 東京理科大学大学院 理工学研究科土木工学專攻 修士課程（广 278-8510 千葉県野田市山崎 2641）
}

\begin{abstract}
A method by means of the volume integral equation for forward and inverse scattering analysis of elastic waves is presented in this paper. The volume integral equation is directly solved by FFT and Krylov subspace iteration technique. The shift operator is also introduced to the inverse scattering analysis to regularize the equation. It is found from the numerical results that the present technique for the volume integral equation is successful for both the forward and inverse scattering problem.
\end{abstract}

Key Words : volume integral equation, Krylov subspace iteration method, FFT, inverse scattering problem

\section{1.はじめに}

波動方程式の数值解法としての積分方程式法は 1980 年代ごろより境界積分方程式を中心に活発に行われて きたことは周知の事実である。それに対して，不均質 波動場の解析手法としての領域積分方程式法の研究は いくつかの事例1)2）を除き活発に行われてきたとはい い難い。この理由として, 領域積分方程式をスタンダー ドな手法で離散化すると, 大規模な密行列が生成され, 近年の高速計算機によっても, 計算が困難となること が挙げられる。

こうした背景の中で，第一著者によって最近になっ て領域積分方程式をスパース行列に変換する手法が提 案された3）4．この方法の特徵は, 領域積分方程式に Fourier 積分変換を施し, 波数領域の積分方程式を区分 一定基底で離散化することにある。このとき，媒質の 摇らぎの波数スペクトルが狭帯域の構造を持てば, 積 分方程式はスパース行列に関する連立一次方程式に変 換された。

しかしながら, 先の離散化手法では, Green 関数の 特異点付近や，媒質の摇らぎのスペクトルのピーク付 近に高い解像度の基底を配置し, その周辺には低い解 像度の基底を用いる繁雑な作業が要求された。 そして, これら異なる解像度の基底の波数領域への配置法は, い くつか試行を経て決定しなければならなかった。この ことは, 積分方程式の解法の実用化に際しての問題に なることは否めない.

本論文の目的の一つは，区分一定基底による離散化 手法の問題の解決法として FFT と反復解法5)を組み合 わせ, 積分方程式を直接的に解く手法を提示すること である.ここでの FFT は波数領域解と空間領域解を結 びつけるために用いられる.FFT は等間隔のデータに 対する手法であることから，異なる解像度の基底で離
散化しなければならないという制約条件の問題は大幅 に改善されることになる。 また，FFTに関しては 3 次 元データに関するものを含め, 近年ではライブラリー $($ たとえば6) $)$ も整備され, 短時間の演算で処理できる ことが期待できる.

本論文のもう一つの目的は, Fourier 積分変換された 領域積分方程式が，媒質の摇らぎと散乱波の関係を明 確に関係づけることを利用して, 散乱波動場から逆に 媒質の摇らぎの推定手法, すなわち, 逆散乱解析手法を 展開することである.ここでの手法の展開は, 前述の積 分方程式による散乱波動場の解析手法と同様に, FFT と反復解法を組合せ, 収束計算によって媒質の摇らぎ を求めて行く方策をとる。なお散乱波動場から逆に媒 質中のクラックなどを検出する, いわゆる逆散乱問題 についての研究は，これまでにも精力的に行われてき た.そして，多数の論文や成書 (たとえば7)-9) $)$ にま とめられている。こうした背景の中でも，媒質の不均 質性の推定などは, 今後の検討に待つべきことも多い と考えられる。本論文で展開される手法は，全散乱波 動場を既知として出発する制約条件があるものの, 収 束計算によって媒質の摇らぎを推定することを目指す. 本論文では, 提示された手法の有効性をいくつかの数 值計算によって実証する。

\section{2. 領域積分方程式による波動解析の定式化}

\section{1 問題の定義}

図-1に示すように, 無限領域の弾性媒質の不均質領 域に平面波が入射し散乱波を生じる問題を考える。以 下の議論では，不均質領域の情報を与えて散乱波を求 める解析と，散乱波動場から逆に媒質の不均質性を求 める解析を扱う。 


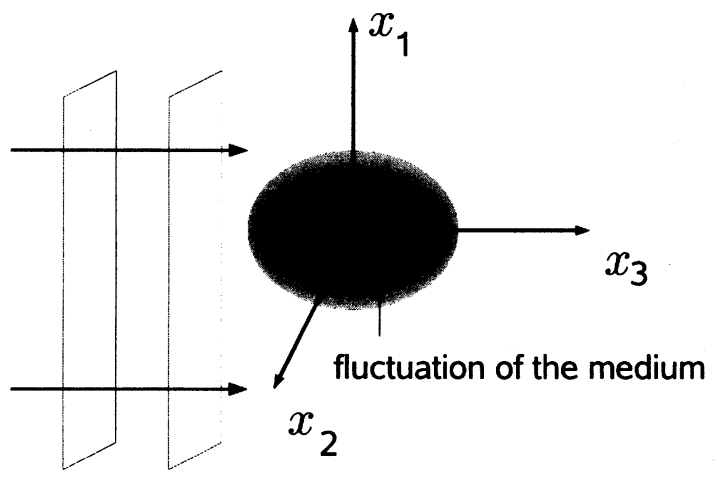

Plane Incident wave

図-1 本論文で扱う問題

定式化において，媒質の不均質性をどのように定義 するかは，基本的な問題である。ここでは，次のよう に Lamé 定数の変動で媒質の不均質性を記述する.

$$
\begin{aligned}
& \lambda(\vec{x})=\lambda_{0}+\tilde{\lambda}(\vec{x}) \\
& \mu(\vec{x})=\mu_{0}+\tilde{\mu}(\vec{x}), \quad\left(\vec{x} \in \mathbb{R}^{3}\right)
\end{aligned}
$$

ここに, $\vec{x}=\left(x_{1}, x_{2}, x_{3}\right) \in \mathbb{R}^{3}$ は 3 次元空間の点で添 字により座標成分を表す。また, $\lambda_{0}$ および $\mu_{0}$ は Lamé 定数が空間的に一定の部分でバックグラウンドの Lamé 定数と呼ぶ。これに対し， $\tilde{\lambda}$ および $\tilde{\mu}$ は Lamé定数の 変動部分であり，媒質の摇らぎと呼ぶこともある，場 の時間因子を $\exp (-i \omega t)$ とし，不均質場の方程式とし て次式を用いる。

$$
\left(\lambda_{0}+\mu_{0}\right) \partial_{i} \partial_{j} u_{j}+\mu_{0} \partial_{j} \partial_{j} u_{i}+\rho \omega^{2} u_{i}=N_{i j} u_{j}
$$

ここに, $t$ は時間, $\omega$ は角振動数, $\rho$ は質量密度, $u_{j}$ は 変位場。 $\partial$ は偏微分の演算子, $N_{i j}$ は媒質の不均質性に 関連して現れる演算子で次式で表現できる。

$$
\begin{aligned}
N_{i j}= & -(\tilde{\lambda}(\vec{x})+\tilde{\mu}(\vec{x})) \partial_{i} \partial_{j}-\tilde{\mu}(\vec{x}) \delta_{i j} \partial_{k} \partial_{k} \\
& -\partial_{i} \tilde{\lambda}(\vec{x}) \partial_{j}-\delta_{i j} \partial_{k} \tilde{\mu}(\vec{x}) \partial_{k}-\partial_{j} \tilde{\mu}(\vec{x}) \partial_{i}
\end{aligned}
$$

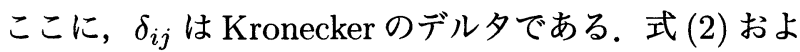
び (3) に示すように, 繰り返し現れる添字に関しては 総和規約を用いることにする。

本論文では空間領域と波数領域の関数を結びつける Fourier変換が重要な役割を果たす。こーでは，Fourier 積分変換と逆変換を次のように定義する.

$$
\begin{aligned}
(\mathscr{F} u)(\vec{\xi}) & =\frac{1}{\sqrt{2 \pi}^{3}} \int_{\mathbb{R}^{3}} u(\vec{x}) \exp (-i \vec{x} \cdot \vec{\xi}) d \vec{x} \\
\left(\mathscr{F}^{-1} u\right)(\vec{x}) & =\frac{1}{\sqrt{2 \pi}^{3}} \int_{\mathbb{R}^{3}} u(\vec{\xi}) \exp (i \vec{x} \cdot \vec{\xi}) d \vec{\xi}
\end{aligned}
$$

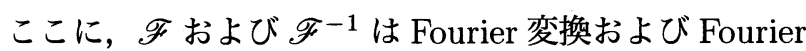
逆変換の演算子, $\vec{\xi}=\left(\xi_{1}, \xi_{2}, \xi_{3}\right) \in \mathbb{R}^{3}$ は波数空間の点 を表す，以降の議論では $u$ の Foureir 変換を $\hat{u}$, Fourier 逆変換を $\check{u}$ と表す場合もある.

\section{2 領域積分方程式およびその Fourier 変換}

式 (2) の不均質場の方程式の右辺を非同次項とみな し積分方程式を作成すれば次式を得る。

$$
u_{i}(\vec{x})=u_{i}^{(I)}(\vec{x})-\int_{\mathbb{R}^{3}} g_{i j}(\vec{x}, \vec{y}) N_{j k}(\vec{y}) u_{k}(\vec{y}) d \vec{y}
$$

ここに, $u_{i}^{(I)}$ は均質場を伝播する平面波, $g_{i j}$ は均質場 の Green 関数で次式で表される.

$$
\begin{aligned}
g_{i j}(\vec{x}, \vec{y})= & \frac{1}{4 \pi \mu_{0}} \delta_{i j}\left[Z_{1}^{T}(r)+Z_{2}^{T}(r)-\left(c_{T} / c_{L}\right)^{2} Z_{2}^{L}(r)\right] \\
& \frac{1}{4 \pi \mu_{0}} \partial_{i} r \partial_{j} r\left[-Z_{3}^{T}+\left(c_{T} / c_{L}\right)^{2} Z_{3}^{L}\right]
\end{aligned}
$$

ここに, $r=|\vec{x}-\vec{y}|, Z$ は波動関数でその添字 $T$ およ び $L$ は波動関数がそれぞれ， $\mathrm{S}$ 波および $\mathrm{P}$ 波であるこ とを示す。また $c_{T}$ および $c_{L}$ は, $\mathrm{S}$ 波と $\mathrm{P}$ 波の速さを 示す．波動関数 $Z$ は次のように定義される.

$$
\begin{aligned}
& Z_{1}^{p}(r)=\frac{1}{r} \exp \left(i k_{p} r\right) \\
& Z_{2}^{p}(r)=-\left(\frac{1}{k_{p}^{2} r^{2}}+\frac{i}{k_{p} r}\right) Z_{1}^{p}(r) \\
& Z_{3}^{p}(r)=Z_{1}^{p}(r)+3 Z_{2}^{p}(r), \quad(p=T, L)
\end{aligned}
$$

ここに，添字の $p$ は $T$ または $L$ の值をとり, $k_{T}$ およ び $k_{L}$ はそれぞれ，S 波および $\mathrm{P}$ 波の波数を示す。

式 (5) の積分方程式を散乱波 $v_{i}(\vec{x})=u_{i}(\vec{x})-u_{i}^{(I)}(\vec{x})$ に関するものに書き換え, 式 (4) で与えた Fourier 積分 変換を施すことで次式を得る4).

$$
\hat{v}_{i}(\vec{\xi})=-\hat{h}_{i j}(\vec{\xi}) \hat{q}_{j}\left(\vec{\xi}-\vec{\xi}_{p}\right)-\hat{h}_{i j}(\vec{\xi}) \hat{w}_{j}(\vec{\xi})
$$

ただし， $\hat{w}_{j}$ は次式で与えられる関数の Fourier 変換で ある。

$$
w_{j}(\vec{x})=N_{j k}(\vec{x}) v_{j}(\vec{x})
$$

なお, 式 (8)の $\hat{h}_{i j}$ は Green 関数の Fourier 変換に 付随して現れる波数領域の関数である. Green 関数の Fourier 変換は, 次のように得られ4),

$$
\hat{g}_{i j}(\vec{\xi}, \vec{y})=\frac{1}{\sqrt{2 \pi}^{3}} \exp (-i \vec{\xi} \cdot \vec{y}) \hat{h}_{i j}(\vec{\xi})
$$

$\hat{h}_{i j}(\vec{\xi})$ の具体的な表現は次式で示されることになる.

$$
\begin{aligned}
\hat{h}_{i j}(\vec{\xi}) & =\frac{\delta_{i i}}{\mu_{0}\left(|\vec{\xi}|^{2}-k_{T}^{2}-i \epsilon\right)}-\frac{\xi_{i} \xi_{j}}{2 \mu_{0}(1-\nu)} \\
& \times \frac{1}{\left(|\vec{\xi}|^{2}-k_{T}^{2}-i \epsilon\right)\left(|\vec{\xi}|^{2}-k_{L}^{2}-i \epsilon\right)}
\end{aligned}
$$

ここに, $\nu$ はバックグラウンドの Poisson 比, $\epsilon$ は無限 小の正数である.

また, 式 (8) の右辺第 2 項の $\hat{q}_{j}$ は入射波と媒質の摇 らぎに関連して得られる関数で, 次の演算のプロセス で現れる。

$$
N_{i j}(\vec{x}) u_{j}^{(I)}(\vec{x})=q_{i}(\vec{x}) \exp \left(i \vec{\xi}_{p} \cdot \vec{x}\right)
$$


ここに, $\vec{\xi}_{p}$ は入射波の波数ベクトルである. 具体的な $q_{i}$ の表現は, たとえば入射波を $x_{3}$ 方向に進行する平面 $\mathrm{P}$ 波とした場合,

$$
u_{i}^{(I)}(\vec{x})=\partial_{i} a \exp \left(i k_{L} x_{3}\right)
$$

を利用することで，次の表現を得る.

$$
\begin{aligned}
& q_{1}(\vec{x})=a k_{L}^{2} \partial_{1} \tilde{\lambda}(\vec{x}) \\
& q_{2}(\vec{x})=a k_{L}^{2} \partial_{2} \tilde{\lambda}(\vec{x}) \\
& q_{3}(\vec{x})=a k_{L}^{2}\left(\partial_{3}+i k_{L}\right)(\tilde{\lambda}(\vec{x})+2 \tilde{\mu}(\vec{x}))
\end{aligned}
$$

ここに, $a$ は入射 $\mathrm{P}$ 波ポテンシャルの振幅を表し, 入 射波数ベクトルは

$$
\vec{\xi}_{p}=\left(0,0, k_{L}\right)
$$

としている. 以上の結果より, 式 (8)の $\hat{q}_{j}\left(\vec{\xi}-\vec{\xi}_{p}\right)$ は 次のように与えられることになる。

$$
\begin{aligned}
& \hat{q}_{1}\left(\vec{\xi}-\vec{\xi}_{p}\right)=a k_{L}^{2} i \xi_{1} \hat{\tilde{\lambda}}\left(\vec{\xi}-\vec{\xi}_{p}\right) \\
& \hat{q}_{2}\left(\vec{\xi}-\vec{\xi}_{p}\right)=a k_{L}^{2} i \xi_{2} \hat{\tilde{\lambda}}\left(\vec{\xi}-\vec{\xi}_{p}\right) \\
& \hat{q}_{3}\left(\vec{\xi}-\vec{\xi}_{p}\right)=a k_{L}^{2} i \xi_{3}\left(\hat{\tilde{\lambda}}\left(\vec{\xi}-\vec{\xi}_{p}\right)+2 \hat{\tilde{\mu}}\left(\vec{\xi}-\vec{\xi}_{p}\right)\right)
\end{aligned}
$$

なお, 平面 $\mathrm{S}$ 波が $x_{3}$ 方向に伝播するときの $q_{j}$ の具体 的な式は論文 ${ }^{4)}$ に示すように,

$$
\begin{aligned}
& q_{1}(\vec{x})=a k_{T}^{2} \tilde{\mu}(\vec{x})-a i k_{T} \partial_{3} \tilde{\mu}(\vec{x}) \\
& q_{2}(\vec{x})=0 \\
& q_{3}(\vec{x})=-i a k_{T} \partial_{1} \tilde{\mu}(\vec{x})
\end{aligned}
$$

となる.ここでも $a$ は入射 $\mathrm{S}$ 波ポテンシャルの振幅で ある。詳細な議論は省略するが，平面 $\mathrm{S}$ 波入射による 散乱問題の定式化も $\mathrm{P}$ 波入射の時と同様に行うことが 可能となる.

\section{3 離散 Fourier 変換と反復解法を組み合わせた散 乱解析手法}

式 (8) を解くために, 先に著者は区分一定基底で方 程式を離散化し，スパース行列を導出する手法を示し た.それに対し，ここでは式 (8) と式 (9) をまとめて表 現し, そこに離散 Fourier 変換と反復解法を適用する 手法を提示する. まず, 式 (8) と式 (9) をまとめると次 式の表現を得る。

$$
\hat{v}_{i}(\vec{\xi})=\hat{f}_{i}(\vec{\xi})-\left(A_{i k} \hat{v}_{k}\right)(\vec{\xi}), \quad\left(\vec{\xi} \in \mathbb{R}^{3}\right)
$$

ここに,

$$
\hat{f}_{i}(\vec{\xi})=-\hat{h}_{i j}(\vec{\xi}) \hat{q}_{j}\left(\vec{\xi}-\vec{\xi}_{p}\right)
$$

であり，媒質の不均質性を既知のデータとすれば，既 知の関数として扱うことができる.また， $A_{i k}$ は次式 で定義される線形演算子である.

$$
A_{i k}=\hat{h}_{i j}(\vec{\xi}) \mathscr{F} N_{j k} \mathscr{F}^{-1}
$$

式 (18) は線形演算子による関数方程式とみなすこと ができる. 式 (18) を数值的に解くために, 演算子 $A_{i k}$ を構成する Fourier 積分変換を離散 Fourier 変換に置き 換える。そして演算子 $A_{i k}$ を有限離散的な点で定義さ れた関数からそれへの線形演算子とすることを考える. Fourier 積分変換を離散 Fourier 変換に置き換えた場合, 演算子 $A_{i k}$ を構成する微分演算子 $N_{j k}$ の扱いが問題と なる.ここでは, 微分演算と Fourier 変換の関係

$$
\partial_{i} f(\vec{x})=\left(\mathscr{F}^{-1}\left(i \xi_{i} \hat{f}\right)\right)(\vec{x})
$$

を用いて離散的な点における微分係数を求めることで 解決する．以上の約束の下で, 演算子 $A_{i k}$ は有限離散 的な点で定義された関数からそれへの線形写像とする ことが可能となる.ここではこの演算子を $A_{(D) i k}$ とし， 式 (18) を次のように書き換える.

$$
\hat{v}_{(D) i}(\vec{\xi})=\hat{f}_{(D) i}(\vec{\xi})-\left(A_{(D) i k} \hat{v}_{(D) k}\right)(\vec{\xi}), \quad(\vec{\xi} \in D)
$$

ここで， $D$ は離散 Fourier 変換が扱う波数空間内の有 限個の離散点の集合である. また, 関数に付けた添字 の $D$ は波数領域の点 $D$ で定義された関数であること を示す。

式 (22) に示された方程式は, 有限次元空間上の線形 演算子による方程式として，連立方程式と同等と考え ることも可能である．ただし, 離散 Fourier 変換の演 算は 3D の FFT を用いることが得策であり, この意味 で, 演算子 $A_{(D) j k}$ の行列としての成分を陽に求めるこ とは，あまり意味のあることではない.

式 (22) を反復的に解くには, Krylov 部分空間反復解 法5)の適用が考えられる. Krylov 部分空間反復解法は 連立方程式

$$
A x=b
$$

に対して, Krylov 部分空間

$$
K_{m}=\operatorname{span}\left\{b, A b, \ldots, A^{m} b\right\}
$$

を構成する。そして，ここから直交基底を取り出すプ ロセスを経由して近似解を求める漸化式の係数を決定 する方法である。ただし， $m$ は反復回数を表す.

式 (22) においても，演算子 $A_{(D) i k}$ を用いて Krylov 部分空間を構成することが可能である。 そして, これに よって近似解が算出できるものと期待できる，ただし， ここでの Krylov 部分空間の構成では, 3D の Fourier 変換と逆変換を繰り返して行く必要があり, どの程度 の計算時間で実現されるかの問題は後述する.

ここで, 離散 Fourier 変換について若干のことを述 ベておく，離散 Fourier 変換および逆変換の演算子を $\mathscr{F}_{D}, \mathscr{F}_{D}^{-1}$ とすれば, これらは式 (4) に対応して, 次 のように表せる.

$$
\begin{aligned}
\left(\mathscr{F}_{D} u\right)(\vec{\xi})= & \frac{\Delta x_{1} \Delta x_{2} \Delta x_{3}}{\sqrt{2 \pi}^{3}} \\
& \times \sum_{m_{1}=0}^{N_{1}-1} \sum_{m_{2}=0}^{N_{2}-1} \sum_{m_{3}=0}^{N_{3}-1} u(\vec{x}) e^{-i \vec{x} \cdot \vec{\xi}} \\
& \left(\vec{x} \in D^{*}, \vec{\xi} \in D\right)
\end{aligned}
$$




$$
\begin{aligned}
\left(\mathscr{F}_{D}^{-1} u\right)(\vec{x})= & \frac{\Delta \xi_{1} \Delta \xi_{2} \Delta \xi_{3}}{\sqrt{2 \pi}^{3}} \\
& \times \sum_{n_{1}=0}^{N_{1}-1} \sum_{n_{2}=0}^{N_{2}-1} \sum_{n_{3}=0}^{N_{3}-1} u(\vec{\xi}) e^{i \vec{x} \cdot \vec{\xi}} \\
& \left(\vec{x} \in D^{*}, \vec{\xi} \in D\right)
\end{aligned}
$$

ここに, $\Delta x_{j},(j=1,2,3)$ は $x_{j}$ 軸におけるデータサン プリング間隔, 同様に $\Delta \xi_{j}$ は $\xi_{j}$ 軸に関するデータサン プリング間隔, $N_{j}$ はデータの個数を表す。また， $D^{*}$ は離散 Fourier 変換で扱う空間点の集合である。ここ で, データサンプリング間隔は

$$
\Delta x_{j} \Delta \xi_{j}=\frac{2 \pi}{N_{j}}
$$

の式により， $N_{j}$ によって拘束され， $\Delta x_{j}, \Delta \xi_{j}$ の二つ を同時に任意に選ぶことはできない. $N_{j}$ が大きい程サ ンプリング間隔は小さく設定できるが, $N_{j}$ は計算機の 性能および解析に必要とされる空間分解能, 波数分解 能を考慮して決定される.

\section{4 離散 Fourier 変換と反復解法を組み合わせた逆 散乱解析手法}

ここでの逆散乱問題は, 弾性定数の空間的な平均値 が既知であるとして，弾性定数の局所的な摇らぎを散 乱波動場から求めるものとして定義する.ただし, 散乱 波動場は全空間で既知とする。波数領域の積分方程式 の特徴として, 媒質の摇らぎと散乱波動場の関係を明 らかにすることが挙げられる。このことを見るために， まず式 (8) と式 (9) をまとめて次のように表現する.

$$
\begin{aligned}
\hat{v}_{i}(\vec{\xi})= & -\hat{h}_{i j}(\vec{\xi}) \hat{q}_{j}\left(\vec{\xi}-\vec{\xi}_{p}\right) \\
& -\hat{h}_{i j}(\vec{\xi}) \mathscr{F} N_{j k}(\vec{x}) \mathscr{F}^{-1} \hat{v}_{k}(\vec{\xi})
\end{aligned}
$$

両辺に $-\hat{h}_{i j}^{-1}$ を乗じて

$$
\hat{\gamma}_{j}(\vec{\xi})=\hat{q}_{j}\left(\vec{\xi}-\vec{\xi}_{p}\right)+\mathscr{F} N_{j k}(\vec{x}) \mathscr{F}^{-1} \hat{v}_{j}(\vec{\xi})
$$

を得る. なお, $\hat{h}_{i j}^{-1}$ は弾性波動場の方程式の演算子の部 分に相当する。ただし，偏微分の演算子は波数で置き 換えられている。この意味で, 波数空間のすべての点 で $\hat{h}_{i j}^{-1}$ は存在すると考えて良い. また,ここでは, 全 散乱波動場を既知量として出発する。従って, 式 (29) の左辺 $\gamma_{j}$ も既知量となることに注意する. 物理的には, $\gamma_{j}$ は散乱波動場を Green 関数で除したものとなる.さ らに, 式 (29) の右辺第 2 項を以下のように表現するこ とを考える。

$$
\mathscr{F} N_{j k}(\vec{x}) \mathscr{F}^{-1} \hat{v}_{j}(\vec{\xi})=\mathscr{F} M_{j k}(\vec{x}) \mathscr{F}^{-1} \hat{q}_{k}(\vec{\xi})
$$

この変形を通して, 式 (29) は $\hat{q}$ を求めるための方程式 となる， $\hat{q}$ は媒質の摇らぎに関わる関数であるから,こ こから媒質の摇らぎを推定することが可能になると期 待できる。

$M_{j k}$ の具体的な表現を求めるために $\alpha_{j}=N_{j k} v_{k}$ と して $\alpha_{j}$ を具体的に計算すると次のようになる.

$$
\begin{aligned}
\alpha_{j}= & -(\tilde{\lambda}+\tilde{\mu}) \partial_{j} \varepsilon-\tilde{\mu} \eta_{j} \\
& -\left(\partial_{j} \tilde{\lambda}\right) \varepsilon-2\left(\partial_{k} \tilde{\mu}\right) \varepsilon_{k j}
\end{aligned}
$$

ここに,

$$
\begin{aligned}
\varepsilon & =\partial_{l} v_{l} \\
\eta_{j} & =\left(\partial_{1}^{2}+\partial_{2}^{2}+\partial_{3}^{2}\right) v_{j} \\
\varepsilon_{j k} & =(1 / 2)\left(\partial_{j} u_{k}+\partial_{k} u_{j}\right)
\end{aligned}
$$

であり，式 (32) の左辺は既知量としての波動場から計 算されることになる。

式 (31) から媒質の摇らぎを分離することを考える. ここでは，媒質の摇らぎに関する状態べクトルを

$$
(\varphi)=\left(\begin{array}{lll}
\partial_{1} \tilde{\lambda} & \tilde{\lambda} & \tilde{\mu}
\end{array}\right)^{T}
$$

として定義し

$$
(\alpha)=[m](\varphi)
$$

と分離してみる.このとき, $[m]$ は次式で示される演算 子となる。

$$
[m]=\left(\begin{array}{ccc}
\varepsilon & \partial_{1} \varepsilon & \partial_{1} \varepsilon+\eta_{1}+2 \varepsilon_{1 l} \partial_{l} \\
0 & \varepsilon \partial_{2}+\partial_{2} \varepsilon & \partial_{2} \varepsilon+\eta_{2}+2 \varepsilon_{2 l} \partial_{l} \\
0 & \varepsilon \partial_{3}+\partial_{3} \varepsilon & \partial_{3} \varepsilon+\eta_{3}+2 \varepsilon_{3} \partial_{l}
\end{array}\right)
$$

この手続きに合わせ，式 (14) を行列とべクトルの積で 次のように表現する.

$$
(q)=[n](\varphi)
$$

このとき， $[n]$ は次式で示される演算子となる.

$$
[n]=\left(\begin{array}{ccc}
a k_{L}^{2} & 0 & 0 \\
0 & a k_{L}^{2} \partial_{2} & 0 \\
0 & a k_{L}^{2}\left(\partial_{3}+i k_{L}\right) & a k_{L}^{2}\left(\partial_{3}+i k_{L}\right)
\end{array}\right)
$$

以上によって, 演算子 $M_{j k}$ は次のように具体的に構成 できることになる。

$$
[M]=[m][n]^{-1}
$$

$[M]$ の導出プロセスは，偏微分の演算子 $\partial_{j}$ を含む行列 の逆をとるなど形式的な演算を積み上げている。しか しながら，ここでは Fourier 変換を採用した手法を展 開するため, 微分演算を Fourier 変換を用いて表現す ることができる。この意味で，演算子 $[M]$ の作用を具 体的に計算することが可能となる.

ここまでの結果をまとめると, 波動場を既知とした 場合の媒質の摇らぎを推定する方程式は次式となる.

$$
\hat{\gamma}_{i}(\vec{\xi})=\hat{q}_{i}\left(\vec{\xi}-\vec{\xi}_{p}\right)+\mathscr{F} M_{i j} \mathscr{F}^{-1} \hat{q}_{j}(\vec{\xi})
$$

この方程式に反復解法を適用するために, シフト演算 子 $S_{\xi_{p}}$ を導入する. すなわち,

$$
S_{\xi_{p}} \hat{q}\left(\vec{\xi}-\vec{\xi}_{p}\right)=\hat{q}(\vec{\xi})
$$

を用いる。このシフト演算子は具体的には Fourier 積 分変換を用いて次のように表せる.

$$
S_{\xi_{p}}=\mathscr{F} \exp \left(-i \vec{x} \cdot \vec{\xi}_{p}\right) \mathscr{F}^{-1}
$$

このシフト演算子を式 (39) の両辺の左から乗じること で，次の方程式を得ることになる.

$$
S_{\xi_{p}} \hat{\gamma}_{i}(\vec{\xi})=\hat{q}_{i}(\vec{\xi})+\mathscr{F} \exp \left(-i \vec{x} \cdot \vec{\xi}_{p}\right) M_{i j} \mathscr{F}^{-1} \hat{q}_{j}(\vec{\xi})
$$


式 (42) に対し前述の反復計算を適用することで $\hat{q}_{i}$ が算 出できる。にしてさらに， $\hat{q}_{i}$ から次のように Lamé 定 数の空間変動の Fourier 変換を算定する.

$$
\begin{aligned}
& \hat{\tilde{\lambda}}(\vec{\xi})=\frac{\hat{q}_{1}(\vec{\xi})}{i \xi_{1} a k_{L}^{2}}=\frac{\hat{q}_{2}(\vec{\xi})}{i \xi_{2} a k_{L}^{2}} \\
& \hat{\tilde{\mu}}(\vec{\xi})=\frac{\hat{q}_{3}(\vec{\xi})}{2 i a k_{L}^{2}\left(\xi_{3}+k_{L}\right)}-\frac{\hat{\tilde{\lambda}}(\vec{\xi})}{2}
\end{aligned}
$$

ただし，式 (43) の演算プロセスでは分母がゼロになる ことを避ける必要がある。この問題は式 (37) で定義さ れた演算子 $[n]$ の逆を求める際にも現れる。具体的に は $\xi_{1}=\xi_{2}=0$ および $\xi_{3}=-k_{L}$ のときに分母はゼロ となり演算は問題を生じる。本論文では，このような ゼロの割算を生じる場合，ゼロを $i \epsilon_{L}$ に置き換え問題 を解決する．ただし， $\epsilon_{L}$ は十分小さな正数である。

以上の手続きで $\hat{\tilde{\lambda}}, \hat{\tilde{\mu}}$ が得られる。これらを Fourier 変換することで媒質の摇らぎが求められることになる.

\section{3. 数值計算例}

\section{1 解析モデルおよび解析条件}

ここでは図-1 に示すように $x_{3}$ 軸に沿って平面 $\mathrm{P}$ 波 が伝播し，不均質領域で波動が乱される問題を扱う。こ こで, 平面入射 $\mathrm{P}$ 波のポテンシャルの振幅は $1.0 \times 10^{-5}$ $\mathrm{km}^{2}$ とした. 数值計算にあたり弾性媒質のバックグラウ ンドの定数は, $\lambda_{0}=4 \mathrm{GPa}, \mu_{0}=2 \mathrm{GPa}, \rho=2 \times 10^{3}$ $\mathrm{kg} / \mathrm{m}^{3}$ とする。.すなわち，このときの $\mathrm{P}$ 波の速度は 2 $\mathrm{km} / \mathrm{s}, \mathrm{S}$ 波の速度は $1 \mathrm{~km} / \mathrm{s}$ である。 また, 波動場の振 動数を $1 \mathrm{~Hz}$ とする.したがって，バックグラウンドの $\mathrm{P}$ 波と $\mathrm{S}$ 波の波数はそれぞれ, $k_{L}=3.14 \mathrm{~km}^{-1}$ および $k_{T}=6.28 \mathrm{~km}^{-1}$ である. また，波数領域の Green 関 数の表現で用いた無限小の正数 $\epsilon$ にいては有限の正 数に置き換え， $\epsilon=0.2$ とした。この值は著者の一人に よる前論文 ${ }^{4)}$ に基づく.

媒質の摇らぎは

$$
\begin{aligned}
& \tilde{\lambda}(\vec{x})=0.1 \exp \left(-A_{\lambda}|\vec{x}|^{2}\right) \\
& \tilde{\mu}(\vec{x})=0.1 \exp \left(-A_{\mu}|\vec{x}|^{2}\right) \quad[\text { GPa }]
\end{aligned}
$$

とする. $A_{\lambda}$ および $A_{\mu}$ の值は媒質の摇らぎの特性を特 徵づけるパラメータである。ここでは，このパラメー 夕を表-1のように与え，ケーススタディを行うことに する。

また，数值計算は AMD opteron $\mathrm{x} 86-64(2.4 \mathrm{GHz})$ の プロセッサーを有する $4 \mathrm{cpu}$ 並列の $\mathrm{PC}$ を使用する. $3 \mathrm{D}$ の FFT には $\mathrm{acml}$ ライブラリー6)を使用する．FFTに 用いるデータサンプリングの個数は $N_{j}=256,(j=$ $1,2,3)$, 空間座標のデータサンプリングの間隔は $\Delta x_{j}=$ $0.25 \mathrm{~km},(j=1,2,3)$ とする.

散乱および逆散乱解析に用いる反復解法の収束条件 は，散乱および逆散乱解析の方程式を次のように一般 的に表現したとき，

$$
A x=b
$$

表-1 解析ケース
\begin{tabular}{|c|c|c|}
\hline 解析ケース & $A_{\lambda}\left(\mathrm{km}^{-2}\right)$ & $A_{\mu}\left(\mathrm{km}^{-2}\right)$ \\
\hline \hline case1 & 0.1 & 0.1 \\
\hline case2 & 0.5 & 0.5 \\
\hline
\end{tabular}

残差ベクトルのノルムが次の条件を満足したときとする.

$$
\|r\| \leq \epsilon_{M}\|b\|
$$

ここに, $r$ は残差べクトルで次式で定義される.

$$
r=A x-b
$$

ただし， $x$ は反復過程で得られる近似解である。 また, 式 (45) の $b$ は既知ベクトルである. 収束判定に用い る $\epsilon_{M}$ は, 散乱解析の計算では 0.001 , 逆散乱解析では 0.01 とする。 これは, 逆散乱解析では, 解の収束が遅 くなるためである。 また, 反復計算における初期べク トルには, 散乱および逆散乱解析とも既知ベクトル $b$ を用いるようにした。

また, 逆散乱解析における式 (37) の演算子 $[n]$ の逆 や式 (43) から Lamé 定数を分離する際に必要となる $\epsilon_{L}$ の值には $1 \times 10^{-5} \mathrm{~km}^{-1}$ を用いることにする.

\subsection{FFT と反復解法を組み合わせた手法による散乱 解析の結果}

\section{(1) case1 の解析結果}

まず，表-1 に示す解析 case1 の定数を用いた場合の 反復計算の収束の状況を図-2 に示す。ここでの反復計 算は，短い漸化式と少ない補助べクトルで構成できる Bi-CGSTAB 法と CGS 法を用いて比較を行っている. 図-2 は横軸が反復回数, 縦軸が相対残差である。両手 法とも, 反復回数の増大とともに相対残差は急速に減 少している．相対残差が 0.001 以下で反復計算を打ち 切る場合には, 両手法とも 2 回の反復計算で収束して いることになる.

なお, 演算時問は両手法とも 2 回で反復計算を打ち 切った場合には $3 \mathrm{~min}$ である. 第一著者が先に示した 区分一定基底による積分方程式の解析手法では 3 回の 反復計算を要し, 解を得るための演算時間は $1 \mathrm{~h} 40 \mathrm{~min}$ であった，数值解析に用いた計算機が異なるため, 単 純な比較は可能ではない. しかし，区分一定基底によ る離散化手法では，演算時間のほとんどをスパース行 列の作成に用い，スパース行列を解くのに $5 \mathrm{~min}$ を要 したことを考慮すれば，ここでの提案手法は演算時間 においても非常に優れていると言える。

また, 積分方程式の解と球関数展開による解の比較 を図 -3 に示す.ここでは, $x_{3}=4 \mathrm{~km}$ 平面で, サンプ リング点での変位ベクトル (実部) の終点をプロットし ている. 球関数展開による解と積分方程式の解は良好 に一致し，提案手法で良好な解が得られていることが 理解できる. 


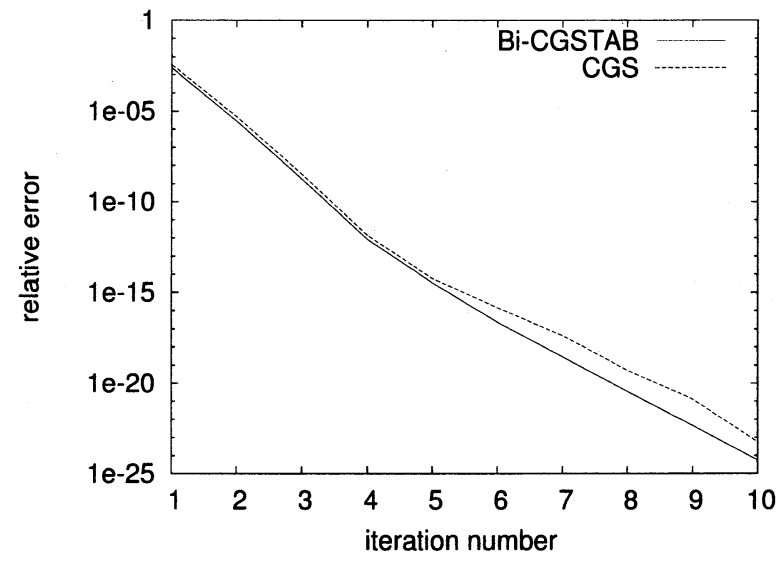

図-2 Bi-CGSTAB 法と CGS 法の収束特性の比較 [case1]

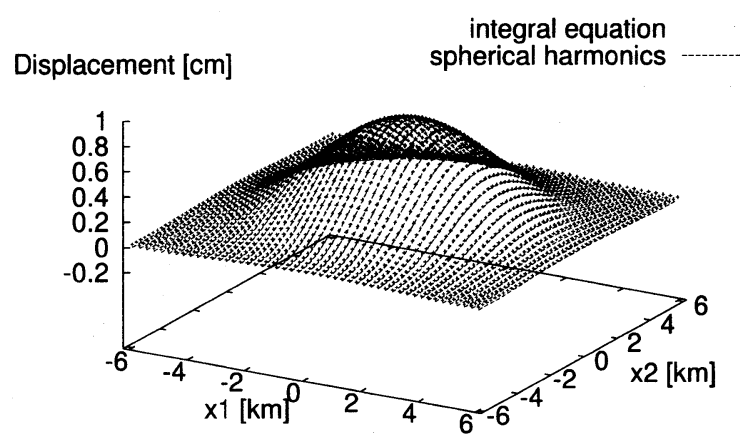

図-3 $x_{3}=4.0 \mathrm{~km}$ での変位分布の比較 [case1]

\section{(2) case2 の解析結果}

次に, 解析 case 2 の定数を用いた場合の反復計算の 収束の状況を図-4に示す。ここでは媒質り摇らざけ広 がりを case1 に比べて狭めたために，収束は case1 に 比べて速くなっている. 相対残差を 0.001 として反復 計算を終了させれば反復回数は Bi-CGSTAB 法と CGS 法とも 1 回で収束することになる.Bi-CGSTAB 法と CGS 法を比較した場合，両者はほぼ同様な収束特性を 示しているものの, Bi-CGSTAB 法が若干有利である.

なお， case2 の媒質の摇らぎの広がりは case1 に比べ て狭まり,このため波数スペクトルは広帯域になって いる. 区分一定基底による離散化手法では，媒質の摇ら ぎのスペクトルの狭帯域性が要求され, case 2 は case1 に比べ区分一定基底による手法では不利となる。しか し, FFT と反復解法を組み合わせた提案手法は, 図-2 と図-4の結果によって, 媒質の摇らぎの帯域性が広く なることで解析が不利になることはない.

図-5 に積分方程式と球関数展開の解の比較を示す. 媒質の摇らぎの広がりを狭めたことで, 散乱波の振幅 は減少している．球関数展開と積分方程式の解は良好 に一致しており，解析手法の妥当性が結論できる。

なお， case2 による空間的な変位分布は case1 に比べ

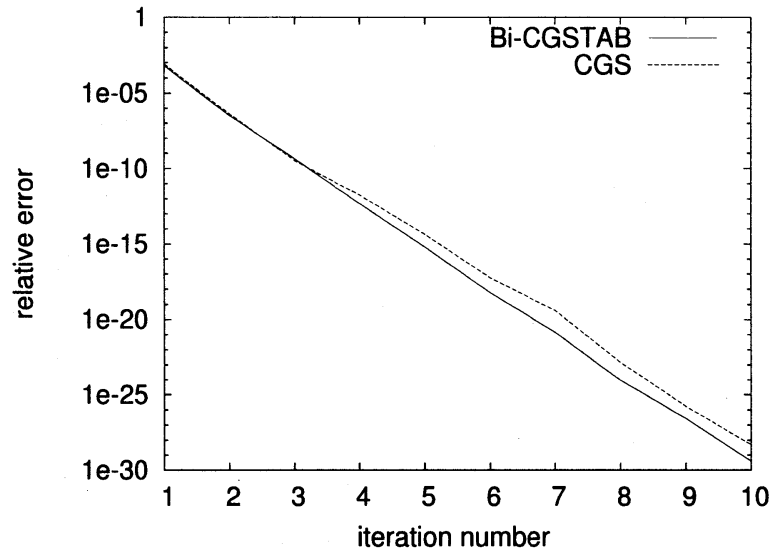

図-4 Bi-CGSTAB 法と CGS 法の収束特性の比較 [case2]

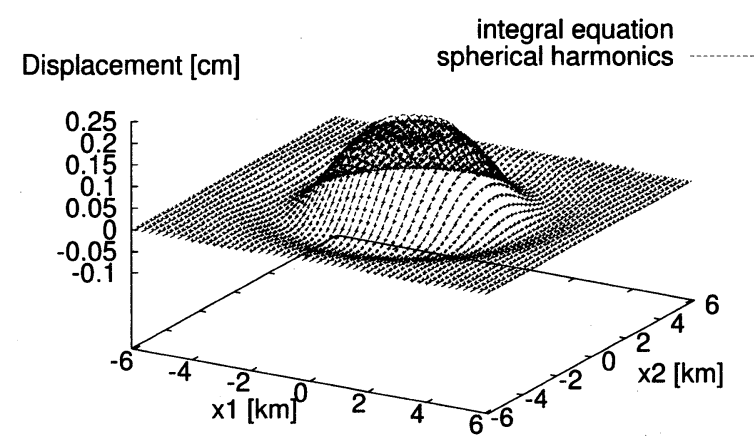

図-5 $x_{3}=4.0 \mathrm{~km}$ での変位分布の比較 $[$ case2]

てやや複雑である，例えば，変位は $x_{1}-x_{2}$ 平面の原 点付近とその周辺部で若干䆶みを生じている。これは, 媒質の摇らぎの空間変動領域を狭めたことで, 摇らぎ の空間勾配が増大し，その影響が表れているものと考 えることができる。

\subsection{FFT と反復解法を組み合わせた逆散乱解析結果}

\section{(1) case1 の解析結果}

逆散乱解析は FFT と Bi-CGSTAB 法を組合せ, 式 (42) を用いて $\hat{q}_{i}$ を算出し，その後，式 (43)により $\tilde{\lambda}, \tilde{\mu}$ を推定する. 波動場は前述の散乱解析で得られた結果 を用いる。逆散乱解析の $x_{1}-x_{2}$ 平面の媒質の摇らぎ の図は, それぞれの case 毎に, 実際の $\tilde{\lambda}, \tilde{\mu}$ の空間分布, $\tilde{\lambda}$ の推定結果, $\tilde{\mu}$ の推定結果の順に示している.

まずはじめに, case1 の結果を考察する. 図-6に, 反 復計算の過程で得られた相対残差のノルムと反復回数 の関係を示す. 散乱解析で得られた相対残差と反復回 数の関係図 -2 , 図-4 と比較して明らかなように, 相対 残差は単調に減少しない。しかも, 相対残差そのもの も, 散乱解析に比べかなり大きくなっている。この結 果, 満足の行く収束の結果を得るのに 10 回以上の反 


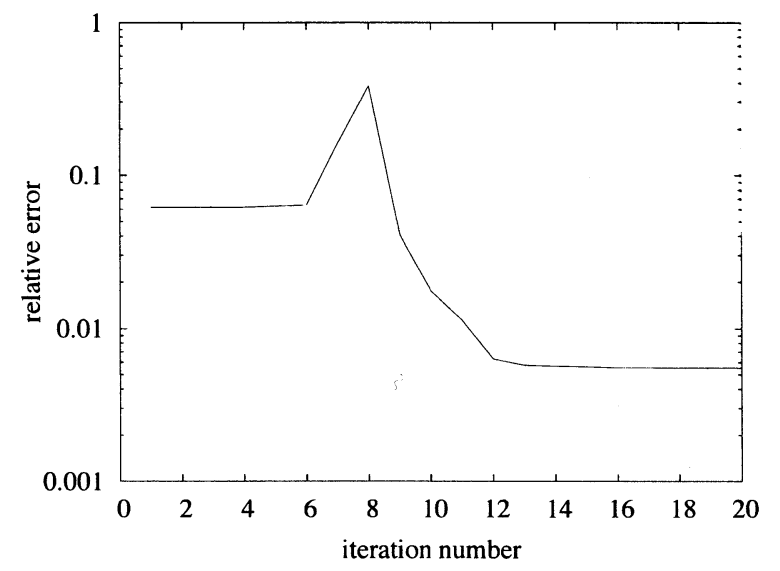

図-6 反復回数と相対残差の関係 [case1]

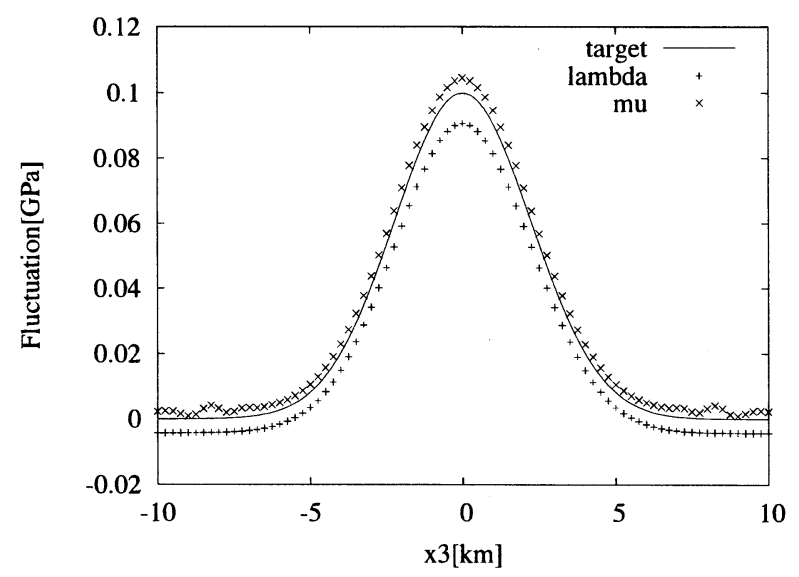

図-7 $x_{3}$ 軸における媒質の摇らぎの振幅の比較 [case1]

復回数が要求される。ここでは，相対残差が 0.01 の場 合に解が収束したものと見なし，12 回目の反復で得た ものを解とした。このとき，要求された演算時間は約 20min であった。

次に, $x_{1}=x_{2}=0 \mathrm{~km}$ における $x_{3}$ 軸上の媒質の摇ら ぎの振幅を図-7に示す. 図中の記号 target は case1 で 与えた媒質の摇らぎ, lambda,mu は本手法によって求 めた $\tilde{\lambda}$ ¿ $の$ 振幅である．また，以下では夕ーゲット と言う言葉を使用するが, これは解析のためにあらか じめ与えた媒質の摇らぎを意味するものとする。図-7 によると, 逆散乱解析で求めた $\tilde{\lambda}$ は, ターゲットに比 ベ小さく評価される一方， $\tilde{\mu}$ は，ターゲットに比べ大 きく評価されていることが分かる。しかし，両者とも 概ね精度良い結果が得られている。

図-8 は case 1 における $x_{3}=0 \mathrm{~km}$ での媒質の摇らぎ を図示したものである。図-9および図-10に本手法に よって得られた $x_{3}=0 \mathrm{~km}$ での $\tilde{\lambda}$ と $\tilde{\mu}$ の推定結果を示

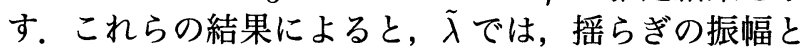
広がりがかなり精度良く求められていることがわかる。 公の推定結果も概ね良好であるが，振幅はやや大きめ に算出されている.

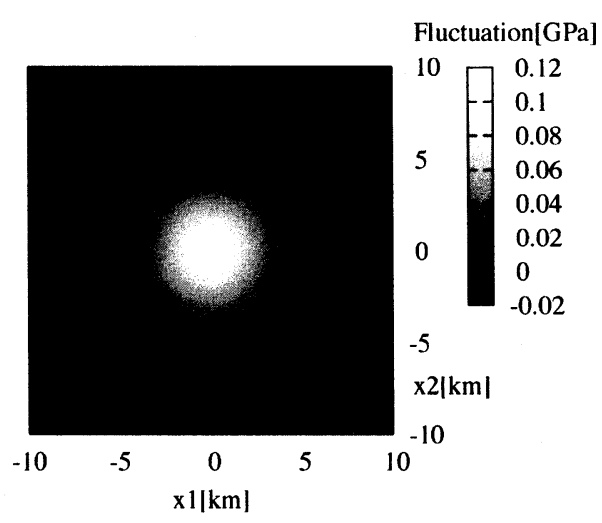

図-8 $x_{3}=0 \mathrm{~km}$ での $\tilde{\lambda}, \tilde{\mu}$ の空間分布 [case1]

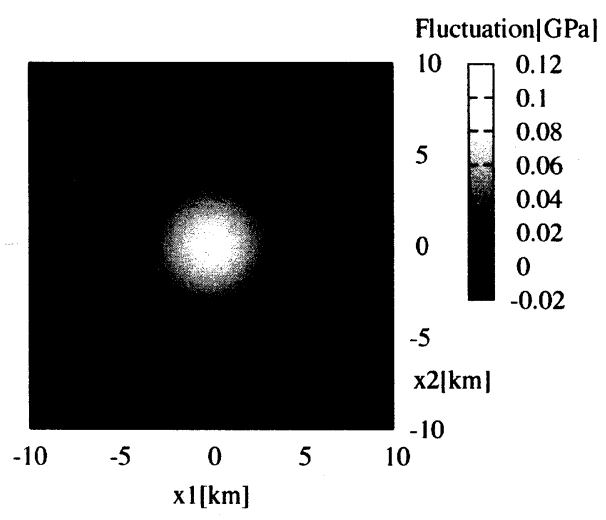

図-9 $x_{3}=0 \mathrm{~km}$ での $\tilde{\lambda}$ の推定結果 [case1]

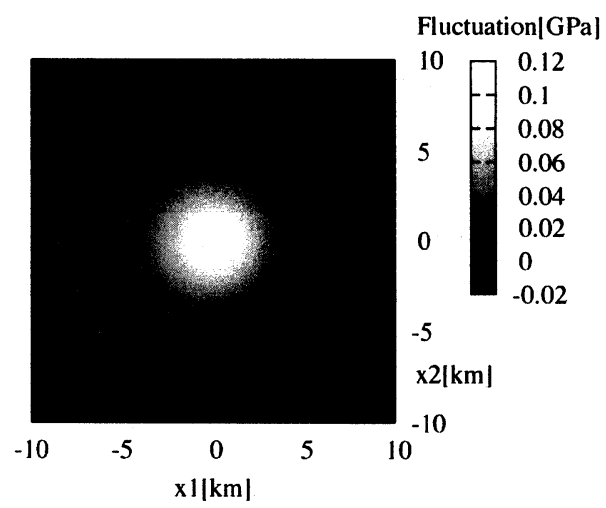

図-10 $x_{3}=0 \mathrm{~km}$ での $\tilde{\mu}$ の推定結果 [case1]

$x_{3}=1 \mathrm{~km}$ での推定結果の考察のために, 図-11に ターゲットとなるべき媒質の摇らぎの空間分布, 図-12 および図-13に $\tilde{\lambda}$ と $\tilde{\mu}$ の推定結果を示す。これらの推 定結果は良好といえるが， $\tilde{\lambda} に$ 関しては，振幅を小さ く評価している。また， $\tilde{\mu} に$ 関しては，広がりを大き く評価していることがわかる. 


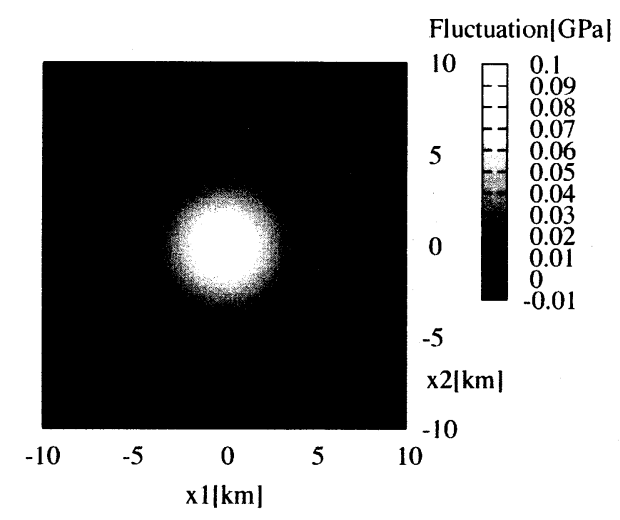

図-11 $x_{3}=1.0 \mathrm{~km}$ での $\tilde{\lambda}, \tilde{\mu}$ の空間分布 [case1]

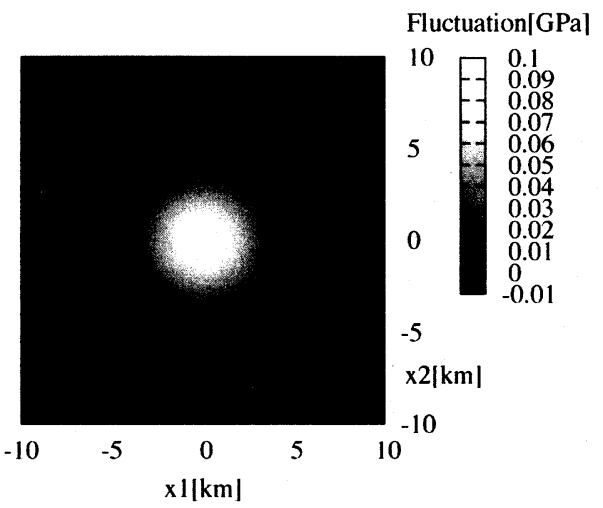

図-12 $x_{3}=1.0 \mathrm{~km}$ での $\tilde{\lambda}$ の推定結果 [case1]

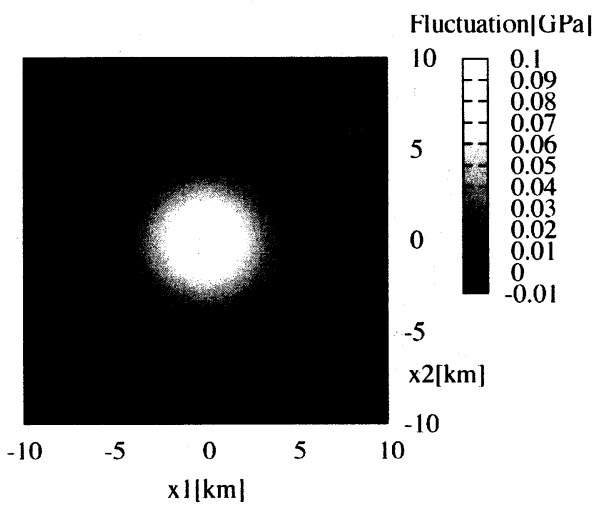

図-13 $x_{3}=1.0 \mathrm{~km}$ での $\tilde{\mu}$ の推定結果 [case1]

\section{(2) case2 の解析結果}

case 2 における媒質の摇らぎの推定のための反復計 算の収束状況を図-14 に示す。ここでの反復計算にも Bi-CGSTAB 法を用いている. 反復計算では, 2 回目で 大きく相対残差が減少し，それ以降は頭打ちになって

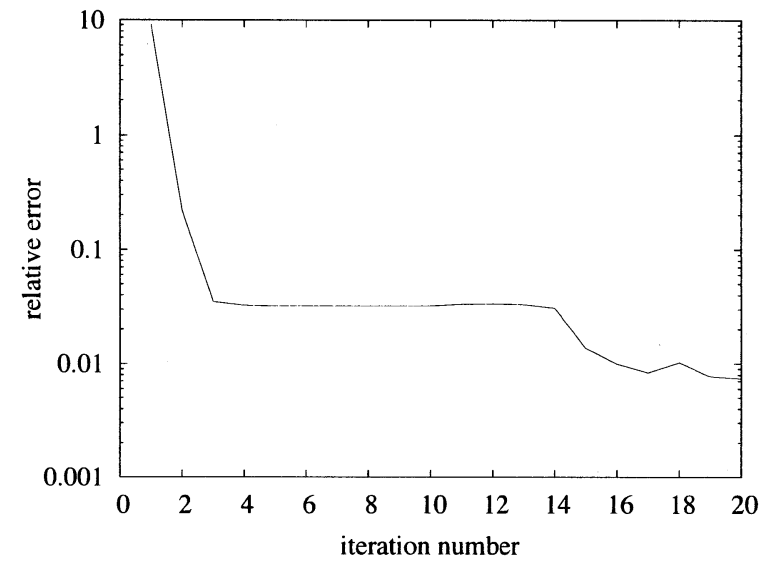

図-14 反復回数と相対残差の関係 [case2]

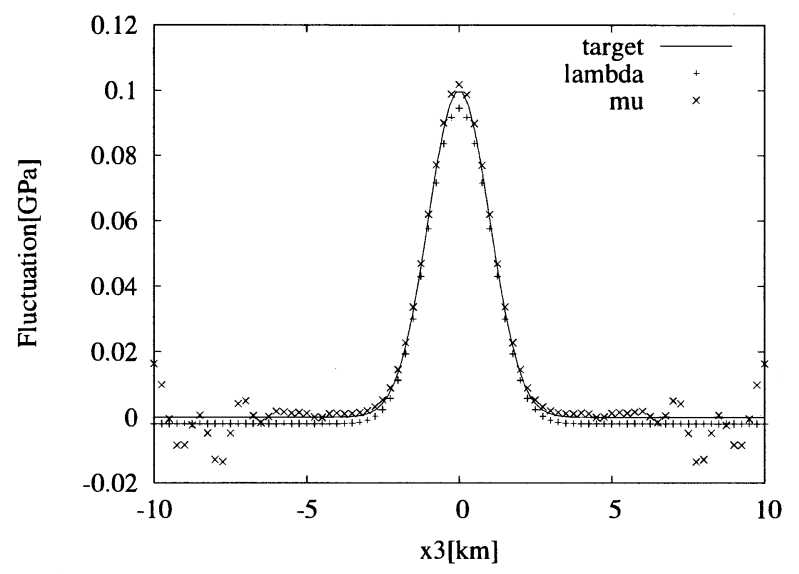

図-15 $x_{3}$ 軸における媒質の摇らぎの振幅の比較 [case2]

いる. 相対残差が 0.01 より小さくなるのは 16 回目以降 であり,ここでは 16 回目の反復計算で解が収束したも のとみなした。このときの演算時間は $25 \mathrm{~min}$ であった。 図-15に $x_{3}$ 軸における媒質の摇らぎの振幅を示す. 図中の記号 target,lambda,mu は, case2 で与えた媒質 の摇らぎ，本手法による $\tilde{\lambda}, \tilde{\mu}$ の推定結果となってい る. 原点を中心に $2 \mathrm{~km}$ 前後までは，ほぼ精度良い結果 が得られていることがわかる。しかし，原点を離れる にしたがって $\tilde{\mu}$ の振幅が振動し始めていることが見て 取れる。

次に, $x_{3}=0 \mathrm{~km}$ における媒質の摇らぎの推定結果 の考察のために, 図-16にターゲットとなるべき媒質 の摇らぎの空間分布を図示する. また， $\tilde{\lambda}$ と $\tilde{\mu}$ の推定 結果を図-17, 図-18に示す. 推定結果によると, $\tilde{\lambda} に$ ついては, 媒質の摇らぎの広がりと振幅をかなり精度 良く捕らえることに成功していることがわかる。一方，

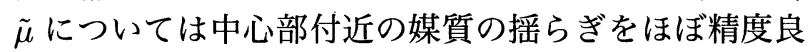
く捕らえているにも関わらず, 周辺部でも媒質の摇らぎ が存在するという結果を算出しており, 誤差を生じて いる.

$x_{3}=1 \mathrm{~km}$ の媒質の摇らぎの空間分布を図-19に, 摇 


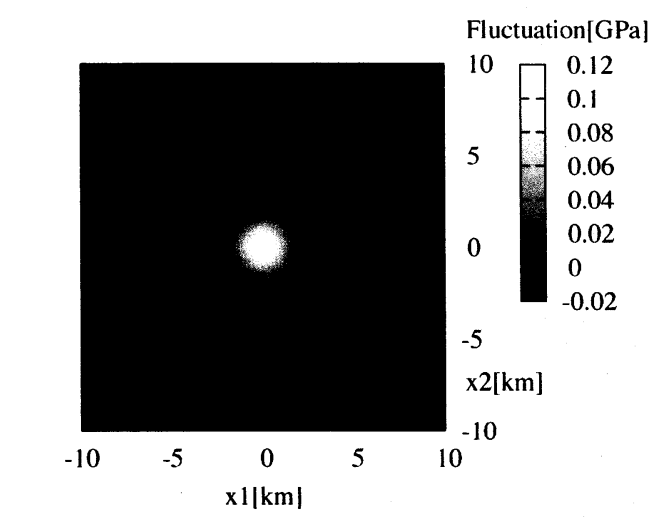

図-16 $x_{3}=0 \mathrm{~km}$ での $\tilde{\lambda}, \tilde{\mu}$ の空間分布 [case2]

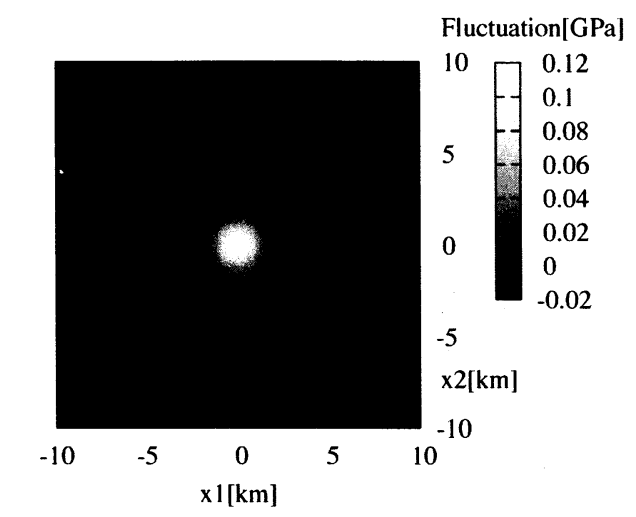

図-17 $x_{3}=0 \mathrm{~km}$ での $\tilde{\lambda}$ の推定結果 [case2]

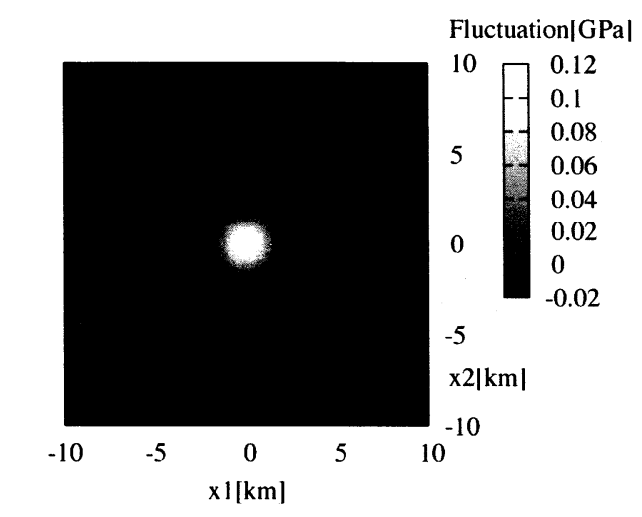

図-18 $x_{3}=0 \mathrm{~km}$ での $\tilde{\mu}$ の推定結果 [case2]

らぎの推定結果を図-20, 図-21 に示す。ここでも， の推定結果は非常に良好である。一方， $\tilde{\mu}$ は，周辺部 での誤差が認められることがわかる， $\tilde{\mu}$ に関する誤差 の原因は，今後の検討を待たなければならない，しか し，例えば $\mathrm{P}$ 波入射の代わりに $\mathrm{S}$ 波入射を試み，せん 断変形を卓越させるなどの工夫も必要と考兄られる.

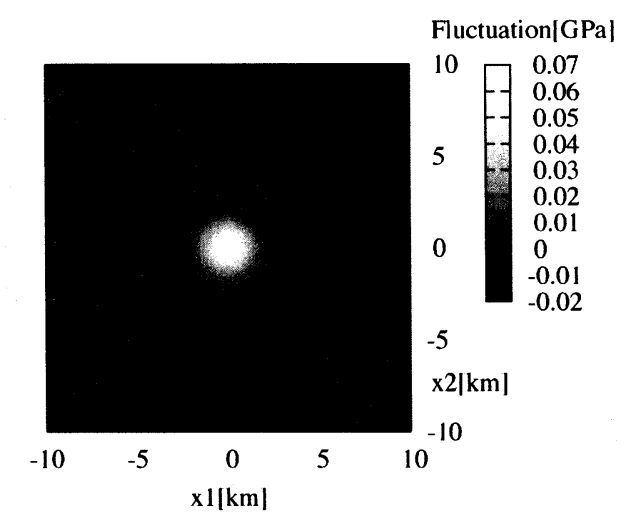

図-19 $x_{3}=1.0 \mathrm{~km}$ での $\tilde{\lambda}, \tilde{\mu}$ の空間分布 [case2]

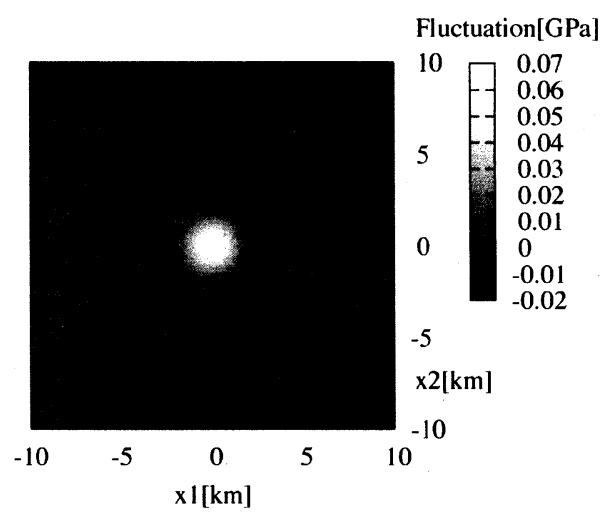

図-20 $x_{3}=1.0 \mathrm{~km}$ での $\tilde{\lambda}$ の推定結果 [case2]

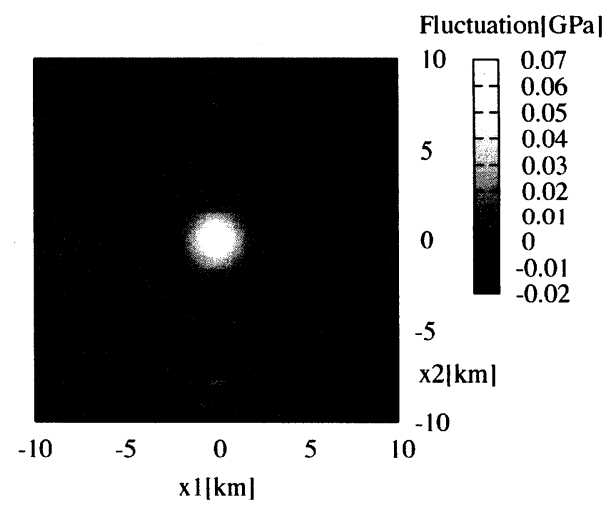

図-21 $x_{3}=1.0 \mathrm{~km}$ での $\tilde{\mu}$ の推定結果 [case2]

なお，ここでの手法では FFT を用いたことにより， 等間隔の空間領域および波数領域デー夕に対する数値 計算が行われた。前論文4)では積分方程式の離散化に際 して, 精度良い解を合成するために波数領域の Green 関数の特異点や摇らぎのスペクトルのピーク付近に高 い解像度の基底を配置するなどの工夫が要求されてい 
た。詳細な検討は今後必要と考えられるが，前論文 ${ }^{4)}$ で示された基底の解像度と離散化の問題は，区分一定 基底を用いた影響の可能性も考えられるであろう。

\section{4. 結論}

本論文では, Fourier 積分変換された波数領域の領域 積分方程式に対し, FFT と Krylov 部分空間反復解法 を適用し，摇らぎを持つ波動場における散乱および逆 散乱解析のための手法を展開した。そしてその手法の 妥当性を検討するために, いくつかの数值計算結果を 示した.

散乱解析においては, 本論文で提案した手法は, 著 者の一人によって展開された区分一定基底による離散 化手法よりも, 演算時間の点でもはるかに有利である. しかも, 区分一定基底による離散化解析で要求された 波数領域への複雑な基底の配置法が不要となり, 媒質 の摇らぎのスペクトル特性への解析の難易度の依存性 も小さくなることが分かった。

逆散乱解析の定式化においては，全波動場が既知で あることを仮定し，領域積分方程式から媒質の摇らぎ を分離した。ささらにシフト演算子を用いて方程式を変 形し，反復計算を適用することで，媒質の摇らぎを算 出した．数値計算によれば, 逆散乱解析で要求さる反 復回数は, 散乱解析に比べかなり多くなるばかりでな く, 残差ノルムも反復回数と共に単調に減少しない場 合があった。しかしながら, ある程度の反復を行うこ とで解は収束し, 媒質の摇らぎの空間分布を捉えるこ とが可能となった.

今回の解析では, 媒質の摇らぎに単調なものを扱っ ている。 また，全波動場が既知であるという制約のも とで媒質の摇らぎが推定できたことを示したに過ぎな
い. 今後は, 複雑な媒質の構造についての解析や, 波 動場についても半無限領域など複雑な境界条件を扱う こと, 更に限られた観測条件のもとで, 全波動場を推 定し, 逆散乱解析を行うことが課題である. 解析振動 数についても, 対象とするモデルに必要な空間分解能 から決定し, その際に必要なデータサンプリングの個 数がどの程度なのか検討も必要になる.

\section{参考文献}

1) Kitahara, M., Niwa, Y., Hirose, S. and Yamazaki, M.: Coupling of numerical Green's matrix and boundary integral equations for the elastodynamic analysis of inhomogeneous bodies on an elastic half-space, Applied Mathematical Modelling, Vol. 8, pp. 397-407, 1984.

2) Niwa, Y., Hirose, S. and Kitahara, M.: Elastodynamic analysis of inhomogeneous anisotropic bodies, International Journal of Solids and Structures, Vol. 22, pp. 1541-1555, 1986.

3）東平光生: 波数領域の定式化に基づく領域積分方程式の 数值解法について, 土木学会論文集, No.808/I-74, pp. 163-173, 2006

4) 東平光生: Fourier 積分変換を用いた領域積分方程式に よる摇らぎを持つ弾性波動場の解析, 土木学会論文集 $\mathrm{A}$, Vol.62, No.4, pp.936-949, 2006

5) 藤野清次, 張紹良: 反復法の数理, 応用数値計算ライブ ラリー, 朝倉書店, 1996

6) http://www.softek.co.jp/SPG/Pgi/TIPS/acml.html

7）廣瀬壮一: 定量的超音波非破壊評価とその周辺技術, 応 用力学論文集, Vol.7, pp.3-12, 2004

8) Colton, D. and Kress, R. Inverse acoustic and electromagnetic scattering theory, Berlin, Springer, 1998.

9) 小林昭一編著, 波動解析と境界要素法, 京都大学出版会, 2000.

(2007 年 4 月 12 日受付) 